\title{
Anti-microbial and Anti-cancer Properties of Echinocystic Acid Extracted from Luffa cylindrica
}

Garai $\mathbf{S}^{1 *}$, Ghosh $\mathbf{R}^{2}$, Bandopadhyay $\mathrm{PP}^{3}$, Mandal NC ${ }^{2}$ and Chattopadhyay $\mathrm{A}^{3}$

${ }^{1}$ Organic and Medicinal Chemistry Division, CSIR-Indian Institute of Chemical Biology, Kolkata-700032, India

${ }^{2}$ Department of Botany, Visva-Bharati, Santiniketan-731235, West Bengal, India

${ }^{3}$ Department of Zoology, Visva-Bharati, Santiniketan-731235, West Bengal, India

\begin{abstract}
Triterpenoids are the most ubiquitous non-steroidal secondary metabolites in terrestrial and marine flora and fauna occurring in the free form as well as in the forms of ether, ester and glycosides. The diverse structural types of triterpenoids with useful biological activities, identification, biosynthesis for feed industry increases interest in triterpenoids. The widely occurring plant $L$ uffa cylindrica was investigated for active triterpenoid sapogenins. The triterpenoid sapogenins were isolated by solvent extraction followed by chromatography and were defined by newer spectroscopic methods. These triterpenoid sapogenins from Luffa cylindrica were isolated and characterized. The anti-microbial and anti-cancer properties of echinocystic acid will be discussed.
\end{abstract}

Keywords: Luffa cylindrica; Anti-microbial activity; Anti-cancer activity; Disc Diffusion assay; MTT assay

\section{Introduction}

Triterpene of diverse structural types are widely distributed in terrestrial and marine sediments, prokaryotes as well as eukaryotes. The triterpenoids have a range of unique and potentially usable biological effects. The most important triterpenoid structures are oleanane, ursane, lupane and dammarane-euphane triterpenoids on biological point of view. Luffa cylindrica (Cucurbitaceae) is a traditionally important medicinal plant. It is widely distributed in tropical and subtropical areas throughout India. It is used in clinical problems relating to child birth. The chemical constituents such as sapogenins, saponins and proteins of Luffa cylindrica used as potentially effective clinical agent in health care in many communities reported [1-4]. The saponins and sapogenins isolated from the plant have the same oleanane type skeleton. The two major sapogenins of the plants are mainly oleanolic acid (1) and echinocystic acid (2) [5]. Its seed and fruits are used as a vegetable either prepared like squash or eaten like cucumbers. Khajuria et. al [6] reported the immunomodulatory effects of two oleanane sapogenins, oleanolic acid (1) and echinocystic acid (2) in mice isolated from Luffa cylindrica. In this study, the anti-microbial and anti-cancer properties of oleanane triterpenoid sapogenin, echinocystic acid (2) will be discussed.

\section{Materials and Methods}

\section{Materials}

Seeds of Luffa cylindrica were collected from Jammu, India and identified in the Botany Department of Regional Research Laboratory (Formerly RRL, CSIR-IIIM), Jammu. The voucher specimen is deposited in the herbarium of the institute. Dulbecco's Modified Eagle's Medium (DMEM), Roswell Park Memorial Institute (RPMI)-1640 culture media, fetal bovine serum (FBS), penicillin-streptomycin antibiotic solution, phytohemagglutinin (PHA-M) and 3-[4,5-dimethylthiazol2-yl]-2,5- diphenyltetrazolium bromide (MTT) were purchased from HiMedia (Mumbai, India). Heparin and trypan blue were purchased from SRL (India); Histopaque, were procured from Sigma-Aldrich (St Louis, MO, USA).

\section{Sample preparation}

The methanolic extract $(60 \mathrm{~g})$ of the defatted powdered seeds of $L$. cylindrica was hydrolysed with aqueous $\mathrm{MeOH}-\mathrm{HCl}$ under reflux for 4 $\mathrm{h}$. The acid hydrolysate was separated into acidic and neutral fractions by treatment with a saturated solution of $\mathrm{NaHCO}_{3}$. The acidic fractions were separately subjected to column chromatography on silica gel using n-Hexane- $\mathrm{CHCl}_{3}$ in various ratios 9:1, 3:1, 1:1 and $\mathrm{CHCl}_{3}$ $\mathrm{MeOH}$ (24:1) and similar fractions so obtained were further purified by preparative TLC $\left(\mathrm{CHCl}_{3}\right.$-Pyridine- $\mathrm{H}_{2} \mathrm{O}$ 9:0.5:0.5) followed by crystallization. Thus, two sapogenins, $1(950 \mathrm{mg})$ and $2(200 \mathrm{mg})$ were obtained. The two sapogenols were identified by IR, NMR and ESIMS. The two polar sapogenins are oleanolic acid (1) $\mathrm{mp} .308^{\circ} \mathrm{C}-310^{\circ} \mathrm{C}$ and echinocystic acid (2), mp. $300^{\circ} \mathrm{C}-305^{\circ} \mathrm{C}$. The echinocystic acid (2) was dissolved in non-toxic organic solvent dimethyl sulphoxide (DMSO) and stored at $4^{\circ} \mathrm{C}$ until use.

\section{Microorganisms}

The standard bacterial strains used as test organisms were obtained from Microbial Type Culture Collection (MTCC) from Institute of Microbial Technology, Chandigarh, India. They are belonged to the Gram Positive and Gram-negative category. The Gram-positive food borne pathogens are Bacillus subtilis (MTCC121), Staphylococcus aureus (MTCC96) and Listeria monocytogenes (MTCC657). Escherichia coli (MTCC1667) and Pseudomonas aeruginosa (MTCC741) are Gram negative bacteria. Salmonella typhimurium (MTCC98) is most predominating food spoilage human pathogenic Gram-negative bacteria.

\section{Anti-bacterial activity screening}

The Anti-bacterial screening of echinocystic acid (2) was determined by Disc Diffusion method of Bauer et al. [7] against some Gram positive and Gram negative pathogenic bacterial strains. This study was performed using $2500 \mu \mathrm{g} / \mathrm{ml}, 250 \mu \mathrm{g} / \mathrm{ml}, 25 \mu \mathrm{g} / \mathrm{ml}$ and 2.5

*Corresponding author: Garai S, Organic and Medicinal Chemistry Division CSIR-Indian Institute of Chemical Biology, 4 Raja S.C. Mullick Road, Jadavpur, Kolkata-700032 India, Tel: 009474767565, 91-33-2499-5947, Fax: 91-33-24735197/2414-9475; E-mail: saraswatigarai@iicb.res.in

Received January 18, 2018; Accepted February 05, 2018; Published February 12, 2018

Citation: Garai S, Ghosh R, Bandopadhyay PP, Mandal NC, Chattopadhyay A (2018) Anti-microbial and Anti-cancer Properties of Echinocystic Acid Extracted from Luffa cylindrica. J Food Process Technol 9: 717. doi: 10.4172/2157. 7110.1000717

Copyright: ( 2018 Garai S, et al. This is an open-access article distributed under the terms of the Creative Commons Attribution License, which permits unrestricted use, distribution, and reproduction in any medium, provided the original author and source are credited. 
$\mu \mathrm{g} / \mathrm{ml}$ of echinocystic acid (2). The inhibition zones were obtained at $250 \mu \mathrm{g} / \mathrm{ml}$ and values were found to be at one fourth of $250 \mu \mathrm{g} / \mathrm{ml}$ of oleanolic acid (1). Ciprofloxacin was used as positive controls.

Anti-microbial mode of action of Echinocystic acid (2) on Gram positive and Gram negative bacterial cells by counting colony forming units (CFUs)

Echinocystic acid (2) once applied to actively growing liquid culture (exponential phase of growth) of Listeria monocytogenes and Salmonella typhimurium and their colony forming units (CFU) were counted for next 24 hours along with untreated control.

The echinocystic acid (2) at its MIC was treated on actively growing culture ( 8 hrs grown) and allowed to grow further till 24 hrs. In every two hours interval aliquot of culture (both treated and untreated) was withdrawn aseptically diluted serially with sterilized distilled water and plated into nutrient agar medium, incubated at $37^{\circ} \mathrm{C}$ for another 24 hrs. The colonies appeared were counted per $\mathrm{ml}$ of culture broth [7-11].

\section{Antifungal activity screening}

The antifungal screening of echinocystic acid (2) was determined by same Disc Diffusion method of Bauer et al. [7] against Candida albicans MTCC3018. Fluconazole was used as standard.

\section{Cell culture}

MCF7 and MDA-MB-231 breast cancer cell lines were procured from the National Centre for Cell Science (Pune, India). Cell culture was done according to the description of Banerjee et al. [12]. Briefly, cells were grown in DMEM, supplemented with $1 \%$ penicillinstreptomycin and $10 \%(\mathrm{v} / \mathrm{v}) \mathrm{FBS}$ solution at $37^{\circ} \mathrm{C}$ in a humidified $\mathrm{CO}_{2}$ incubator $\left(5 \% \mathrm{CO}_{2}\right)$ (Thermo Fisher Scientific, Waltham, MA, USA).

\section{MTT assay}

Cells $\left(1 \times 10^{4}\right)$ were seeded per well of a 96-well plate and incubated in standard culture condition for $24 \mathrm{~h}$. After that, complete DMEM media was removed and cells were replenished with incomplete media (without FBS) and then treated with different concentrations of echinocystic acid (2). Both negative and positive controls were used along with the treated groups. Treated cells were incubated at $37^{\circ} \mathrm{C}$ in the presence of $5 \%$ humidified $\mathrm{CO}_{2}$ for $48 \mathrm{~h}$, and the proliferation rates were estimated by MTT assay at $595 \mathrm{~nm}$ using an ELISA reader (Bio Rad, USA). The percentage of viable cells was calculated taking viability of untreated cells as $100 \%$.

\section{Isolation of human peripheral blood mononuclear cells; culture and MTT assay}

Fresh blood was collected from five healthy non-smokers, nonalcoholic male donors (21-25 years of age) with written informed consents by venipuncture into heparinised falcon tubes. Blood was collected by pathologists employed at the university hospital, under the supervision of medical doctors. All studies were performed complying fully with the approved "Ethical Guidelines for Biomedical Research on Human Subjects" formulated by the Indian Council of Medical Research, India. The work was reviewed and approved by the Institutional Ethics Committee for Human Research of Visva-Bharati University. Human peripheral blood mono nuclear cells (HPBMC) were isolated according to the method of Bøyum [13] with minor modification. Blood was layered over equal amount of Histopaque and centrifuged at $1000 \times \mathrm{g}$ for $30 \mathrm{~min}$. The buffy coat was aspirated into 3-5 $\mathrm{ml} \mathrm{PBS}$ and centrifuged at $1000 \times \mathrm{g}$ for $10 \mathrm{~min}$, and the washing process was repeated thrice. The pellet was resuspended in RPMI-1640 media $\left(1 \times 10^{6}\right.$ cells $\left./ \mathrm{ml}\right)$ and viability was checked using the trypan blue dye exclusion method.

Cell viability was found to be $>95 \%$, which indicated successful isolation. Isolated HPBLs $(0.5 \mathrm{ml})$ were stimulated by PHA and cultured in $5 \mathrm{ml}$ of RPMI-1640 media with 10\% FBS along with antibiotics. After $24 \mathrm{~h}$, cells were treated for $48 \mathrm{~h}$ with respective $\mathrm{IC}_{50}$ doses of echinocystic acid (2) in MCF7 and MDA MB 231 cell lines and proliferation rates were estimated by MTT assay at $595 \mathrm{~nm}$ using a ELISA reader (Bio Rad, USA). Percentage of viable cells was calculated taking viability of untreated cells as $100 \%$.

\section{Statistical analysis}

Results were expressed as mean \pm standard error (SE). Statistical analysis of the data was performed by paired $t$-test, and $p<0.05$ were considered significant.

\section{Results and Discussion}

In the DiscDiffusion study, the anti-microbial activity of echinocystic acid (2) was evaluated against all the Gram-positive Bacillus subtilis, Listeria monocytogenes, Staphylococcus aureus and Gram-negative Escherichia coli, Salmonella typhimurium, Pseudomonas aeruginosa bacteria (Table 1) [8-11]. It showed significant anti-microbial potential against the Gram-positive Bacillus subtilis, Listeria monocytogenes, Staphylococcus aureus and Gram-negative Salmonella typhimurium bacteria (Figure 1). The echinocystic acid (2) could kill all the tested bacteria at $250 \mu \mathrm{g} / \mathrm{ml}$ and maximum zones of inhibition were obtained using highest concentration $(2500 \mu \mathrm{g} / \mathrm{ml})$ suggests that Echinocystic acid (2) killed the Gram-positive food borne pathogens Bacillus subtilis, Listeria monocytogenes, human pathogenic Staphylococcus aureus and one Gram-negative Salmonella typhimurium bacterium. MIC of echinocystic acid (2) obtained against all the tested bacteria was $62.2 \mu \mathrm{g} /$ $\mathrm{ml}$. A clear cut bacteriostatic pattern of growth for both the strains, the Gram-positive Listeria monocytogenes and Gram-negative Salmonella typhimurium was found in the anti-microbial mode of action study (Table 2). Figures 2 and 3 clearly indicated static type of mode of action upon treatment with echinocystic acid (2) at its MIC. Echinocystic acid (2) has moderate anticandidal activity against Candida albicans (Table 3). With regard to the structure-activity relationship it was suggested that both the hydroxyl and carboxyl groups are important

\begin{tabular}{|c|c|}
\hline Bacterial strains & Echinocystic acid (2) \\
\hline Bacillus subtilis MTCC 121 Gram (+) ve & +++ \\
\hline Listeria monocytogenes MTCC 657 Gram (+) ve & +++ \\
\hline Staphylococcus aureus MTCC 96 Gram (+) ve & +++ \\
\hline Escherichia coli MTCC 1667 Gram (-) ve & - \\
\hline Salmonella typhimurium MTCC 98 Gram (-) ve & ++ \\
\hline Pseudomonas aeruginosa MTCC 741 Gram (-) ve & - \\
\hline,+++ inhibition zone diameter more than $20 \mathrm{~mm} ;-$, no inhibition \\
\hline
\end{tabular}

Table 1: Anti-bacterial screening of Echinocystic acid (2) against six Gram-positive and Gram-negative bacteria.
(1)

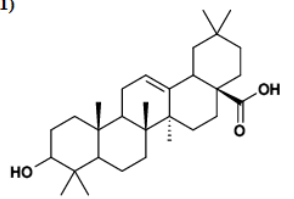

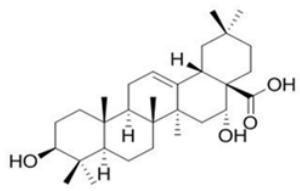

Figure 1: Structures of Oleanolic acid (1) and Echinocystic acid (2). 
Citation: Garai S, Ghosh R, Bandopadhyay PP, Mandal NC, Chattopadhyay A (2018) Anti-microbial and Anti-cancer Properties of Echinocystic Acid Extracted from Luffa cylindrica. J Food Process Technol 9: 717. doi: 10.4172/2157-7110.1000717

Page 3 of 4

for their Anti-bacterial activity of echinocystic acid (2). MTT assay results showed that echinocystic acid (2) inhibited the cell viability of human breast cancer cell lines (Figure 4). Both MCF7 and MDA-MB 231 cell lines showed dose dependent inhibition of cell growth after

\begin{tabular}{|c|c|c|c|c|}
\hline $\begin{array}{c}\text { Log CFU } \\
\text { count at } \\
\text { different } \\
\text { hours }\end{array}$ & $\begin{array}{c}\text { Control } \\
\text { Gram positive } \\
\text { Listeria } \\
\text { monocytogenes }\end{array}$ & $\begin{array}{c}\text { Treated on } \\
\text { actively } \\
\text { growing } \\
\text { culture (8 hrs } \\
\text { culture) }\end{array}$ & $\begin{array}{c}\text { Control } \\
\text { Gram negative } \\
\text { Salmonella } \\
\text { typhimurium }\end{array}$ & $\begin{array}{c}\text { Treated on } \\
\text { actively } \\
\text { growing } \\
\text { culture (8 hrs } \\
\text { culture) }\end{array}$ \\
\hline 0 & 0.8 & -- & 0.7 & -- \\
\hline 2 & 1.0 & -- & 0.9 & -- \\
\hline 4 & 1.2 & -- & 1.3 & -- \\
\hline 6 & 1.9 & -- & 2.0 & -- \\
\hline 8 & 3.0 & 3.0 & 2.9 & 2.9 \\
\hline 10 & 5.2 & 5.2 & 5.0 & 5.0 \\
\hline 12 & 7.6 & 5.2 & 7.4 & 4.8 \\
\hline 14 & 9.4 & 5.1 & 9.3 & 4.8 \\
\hline 16 & 10.7 & 5.0 & 10.5 & 4.6 \\
\hline 18 & 11.0 & 4.8 & 11.2 & 4.5 \\
\hline 20 & 11.3 & 4.5 & 11.6 & 4.3 \\
\hline 22 & 11.4 & 4.3 & 11.7 & 4.2 \\
\hline 24 & 11.4 & 4.2 & 11.8 & 4.1 \\
\hline
\end{tabular}

Table 2: Mode of action of Echinocystic acid (2) on Gram positive and Gram negative bacterial cells by counting colony forming units (CFUs).

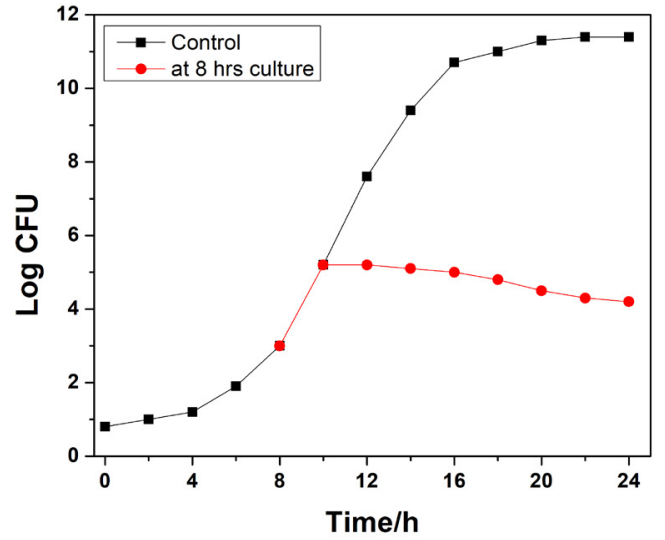

Figure 2: Time-kill curve of Echinocystic acid (2) against Listeria monocytogenes.

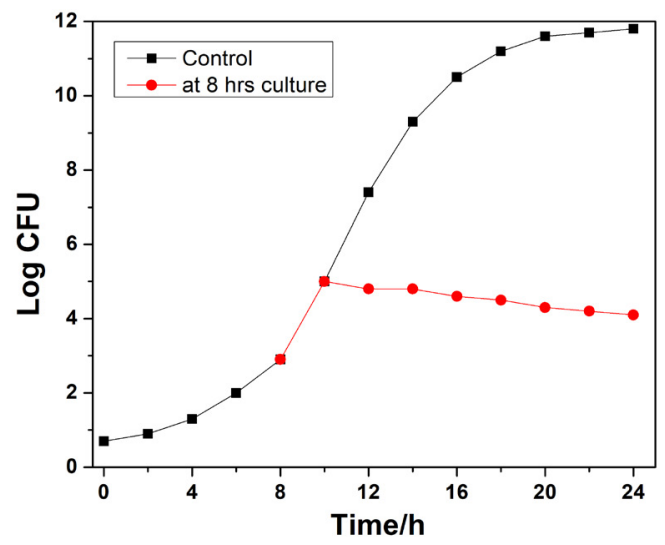

Figure 3: Time-kill curve of Echinocystic acid (2) against Salmonella typhimurium.

\begin{tabular}{|c|c|c|c|}
\hline \multirow{2}{*}{ Fungal species } & $\begin{array}{c}\text { Echinocystic } \\
\text { acid (2) }\end{array}$ & $\begin{array}{c}\text { Echinocystic } \\
\text { acid (2) }\end{array}$ & Fluconazole \\
\cline { 2 - 4 } & MIC $_{100}$ & MIC $_{80}$ & MIC $_{100}$ \\
\hline $\begin{array}{c}\text { Candida albicans } \\
\text { MTCC3018 }\end{array}$ & 300 & 250 & 300 \\
\hline
\end{tabular}

$\mathrm{MIC}_{100}$ and $\mathrm{MIC}_{80}$ : Concentration of echinocystic acid (2) that caused $100 \%$ and $80 \%$ reduction of the growth control respectively.

Table 3: Minimum inhibitory concentration (MIC) in $\mu \mathrm{g} / \mathrm{ml}$ of Echinocystic acid (2)

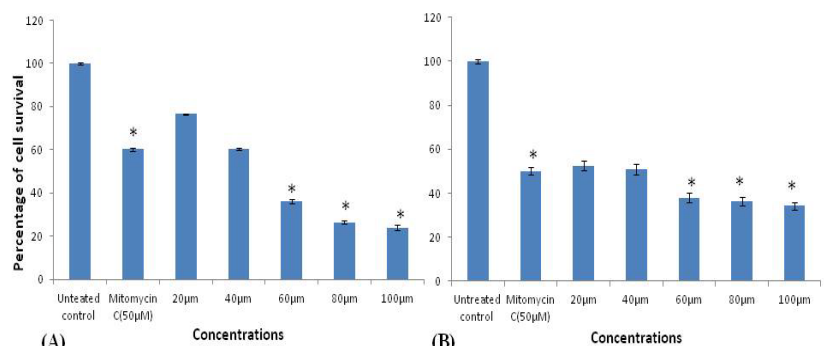

Figure 4: Histograms showing cell survival (\%) of (A) MDA-MB-231and (B) MCF7 cells after treatment with different concentrations of echinocystic acid (2) for $48 \mathrm{~h}$ ( ${ }^{*}$ significantly different from control. p<0.05). Mitomycin C $(50 \mu \mathrm{M})$ was taken as positive control.

treatment with echinocystic acid (2). Significant inhibitory effect was observed at the dose of $60 \mu \mathrm{M}$. Calculated IC $_{50}$ value for MCF7 cell line was $41.72 \mu \mathrm{M}$ and for MDA-MB 231 cell line was $48.17 \mu \mathrm{M}$. Isolated HPBMCs were treated with both these $\mathrm{IC}_{50}$ for $48 \mathrm{~h}$. $96.29 \%$ of cell growth inhibition was observed at $41.72 \mu \mathrm{M}$ which was $84.34 \%$ at the dose of $48.17 \mu \mathrm{M}$. This shows that echinocystic acid (2) is not cytotoxic to normal cells.

\section{Conclusion}

Due to its potential anti-microbial properties echinocystic acid (2) can be considered as natural preservatives in food processing industry to reduce the microbial growth in processed food products. Echinocystic acid has potential anti-cancer activity on human breast cancer cell lines and it can be used in human health care. We are pursuing further studies of anti-microbial and anti-cancer activities of the two major oleanane sapogenins, oleanolic acid (1) and echinocystic acid (2) of the plant to provide a basis for discussion of their activity in relation to their chemical structures. This is the first report of anti-microbial and anti-cancer properties of echinocystic acid of Luffa cylindrica.

\section{Acknowledgement}

Financial support from CSIR, New Delhi is gratefully acknowledged.

\section{References}

1. Azeez MA, Bello OS, Adediji AO (2013) Traditional and medicinal uses of Luffa cylindrica: A Review. J Med Plants Studies 1: 102-111.

2. Nair DU, Saraswathy MP, Kishore N, Reddy Pully N (2010) Phytochemical and antimicrobial evaluation of Luffa cylindrica Linn. leaf and flower extracts: An in-vitro study. Res J Pharm Tech 3: 438-441.

3. Velmurugan V, George S, Surekha PS (2011) Phytochemical and biologica screening of Luffa cylindrica Linn. fruit. Inter J Pharm Tech Res 3: 1582-1585.

4. Muthumani P, Meera R, Mary S, Devi PJ, Kameswari B, et al. (2010) Phytochemical and antiinflammatory, bronchodilator and antimicrobial activities of the seeds of Luffa cylindrica. Res J Pharm Bio Chem Sci 1: 11-21.

5. Yoshikawa K, Arihara S, Wang JD, Narui T, Okuyama T, et al. (1991) Structure of two new fibrinolytic saponins from the seed of Luffa cylindrica ROEM1). Chem Pharm Bull 39: 1185-1188.

6. Khajuria A, Gupta A, Garai S, Wakhloo BP (2007) Immunomodulatory effects 
Citation: Garai S, Ghosh R, Bandopadhyay PP, Mandal NC, Chattopadhyay A (2018) Anti-microbial and Anti-cancer Properties of Echinocystic Acid Extracted from Luffa cylindrica. J Food Process Technol 9: 717. doi: 10.4172/2157-7110.1000717

Page 4 of 4

of two sapogenins 1 \& 2 isolated from Luffa cylindrica in Bulb/C mice. Bioorg Med Chem Lett 17: 1608-1612.

7. Bauer AW, Kirby WMM, Sherries T (1966) Antibiotic susceptibility testing by a standard single disc method. Am J Clin Pathol 45: 493-496.

8. Mondal V Sen SK, Mondal NC (2011) Isolation and characterization of pediocin NV 5 from vacuum-packed fermented meat product. Ind J Microbiol 51: 22-29.

9. Huang G, Mason SL, Hudson JA, Clerens S, Plowman JE, et al. (2014) Proteomic differences between Listeria Monocytogenes isolates from food and clinical environments. Pathogen 3: 920-933.

10. Colagiooprgi A, Bruini H, Aldo Di-Ciccio P, Zanardi E, Ghidini S, et al. (2017) Listeria monocytogenus Biofilms in the wonderland of Food Industry. Pathogen 6: 41.

11. Boukhira S, Balour M, Monsouri LE, Youbi AEHE, Bouarfa M, et al. (2017) Development of natural preservative from Silene vulgaris extract in topical formulation under a challenge test and its stability study. J Appl Pharm Sci 7 : $142-148$.

12. Banerjee PP, Bandyopadhyay A, Nagesh HS, Policegoudra RS, Bhattacharya $\mathrm{S}$, et al. (2017) Mentha arvensis (Linn.) mediated green silver nanoparticles trigger caspase 9 dependent cell death in MCF7 and MDA-MB-231 cells. Breast Cancer: Target Therapy 9: 265-273.

13. Bøyum A (1976) Isolation of lymphocytes, granulocytes and macrophages. Scand J Immunol 5: 9-15. 